\title{
UTILIZATION FACTORS OF PREVENTION MOTHER TO CHILD HIV TRANSMISSION (PMTCT) PROGRAM AMONG PREGNANT WOMEN
}

\author{
Marya Yenita Sitohang \\ Faculty of Public Health \\ Universitas Diponegoro, Semarang, Indonesia \\ Email: maryayenitaIg@gmail.com
}

\begin{abstract}
HIV transmission patterns had changed from high-risk groups to the group of housewives. Housewives will get pregnant and give birth. The possibility of a child contracting HIV from his mother can be prevented by utilizing the PMTCT program optimally. The objective of this research is to analyze the internal and external factors of PMTCT program utilization for pregnant women. This research used a critical review of previous studies (2009-2017). Social structures (education, occupation, and economic status) were not significantly related to the behavior of PMTCT program utilization. However, the availability of information and consultation with health officers (external factors) related to knowledge and perception of pregnant women about HIV and PMTCT program (internal factors). Good knowledge and perception would connect with the behavior of PMTCT program utilization. Negative stigma (external factor) from the family, community, and health officer made pregnant women reluctant to utilize the PMTCT program optimally. In conclusion, the need for increasing the quality of health services to become client-oriented as of widening the scope and optimization of the PMTCT program.
\end{abstract}

Keywords: PMTCT program, utilization factors, pregnant women, HIV

\begin{abstract}
Abstrak
Penularan HIV saat ini telah mengalami perubahan pola transmisi dari kelompok berisiko pada kelompok ibu rumah tangga. Perubahan ini mempengaruhi kualitas hidup seorang ibu hamil dan memiliki kemungkinan untuk menularkan HIV pada anaknya. Hal ini dapat dicegah apabila ibu hamil memanfaatkan pelayanan PMTCT secara optimal. Tujuan dari penelitian ini adalah untuk menganalisis faktor internal dan eksternal pemanfaatan pelayanan PMTCT oleh ibu hamil. Penelitian ini manggunakan metode kajian literatur berupa telaah kritis dari penelitan terdahulu (2009-20I7). Struktur sosial (pendidikan, pekerjaan dan status ekonomi) tidak langsung berhubungan dengan perilaku pemanfaatan pelayanan PMTCT. Namun, ketersediaan informasi dan konsultasi (faktor eksternal) berkaitan dengan pengetahuan dan persepsi ibu (faktor internal) mengenai HIV maupun manfaat PMTCT. Pengetahuan dan persepsi yang baik dari ibu akan berkaitan langsung dengan pemanfaatan pelayanan PMTCT. Faktor eksternal berupa stigma negatif baik dari keluarga maupun masyarakat membuat ibu hamil enggan untuk memanfaatkan pelayanan PMTCT. Pada kesimpulannya, perlu peningkatan mutu pelayanan PMTCT yang bersifat client-oriented sehingga memperluas jangkauan serta optimalisasi pemanfaatan pelayanan PMTCT.
\end{abstract}

Kata kunci: pelayanan PMTCT, faktor pemanfaatan, ibu hamil, HIV 


\section{INTRODUCTION}

Vertical transmission of Human Immunodeficiency Virus (HIV) from mother to child is now a global and national focus in preventing the spread of Acquired Immune Deficiency Syndrome (AIDS). The Ministry of Health since 2013 has established guidelines for preventing HIV / AIDS transmission from mother to child through Minister of Health Regulation No. 5I of 2013 (Ministry of Health of the Republic of Indonesia, 2013). These guidelines are strengthened by the WHO's global targets in eliminating HIV / AIDS, which in 2015 emphasized the elimination of new HIV infections in children and maintaining maternal safety (Ministry of Health, 2012).

In recent years, there has been a change in the pattern of HIV transmission from high-risk groups to the general public. Risk groups such as sex workers only contributed $3.4 \%$ while the general public, such as housewives, private employees, and entrepreneurs contributed $40.3 \%$ in the number of AIDS cases in Indonesia in 2016 (Director General of Disease Prevention and Environmental Control Ministry of Health Republic of Indonesia, 20I7). This phenomenon is in line with the Ministry of Health data, which shows that $50.3 \%$ of HIV transmission occurs through sexual intercourse with sex partners (heterosexual) (Pusdatin Ministry of Health $\mathrm{RI}, 2016 \mathrm{c})$.

Housewives, most of them will or have become pregnant women, are a vulnerable group in HIV transmission. As many as 4.9 million housewives marry high-risk men. Besides, data shows that 6.7 million men in Indonesia are sex buyers (Indonesian Family Planning Association, 20I6). Housewives have an inability to control their partner's sexual behavior outside the home, especially when their partners have high mobility jobs. It is in line with research conducted in Ghana in 20I7, which showed that one of the factors that bridge the occurrence of risky sexual behavior is population mobility. This activity allowed sexual relations with different people in a short period (Cassels et al., 20I7).
The quality of health of pregnant women affects the degree of public health. HIV infection is one of the leading health problems and one of the infectious diseases that can affect maternal and child mortality (Ministry of Health of the Republic of Indonesia, 20I2). Research conducted in Tanzania in 2016 showed that HIV / AIDS in pregnant women contributed to causing $8.7 \%$ of maternal deaths (Maro et al., 2016).

The urgency of the HIV / AIDS problem is getting bigger. It is consistent with research conducted in 8 provincial capitals of Indonesia, which shows that HIV prevalence in pregnant women continues to increase from 2003-2009 (Muhaimin and Besral, 20II). The Ministry of Health also projects that HIV / AIDS prevalence in pregnant women will increase from $0.38 \%$ to $0.49 \%$ in 2016 (Indonesian Ministry of Health, 20I6a). In addition, based on United Nations Program Program on HIV and AIDS (UNAIDS) estimation data, there has been an increase in children aged o-I4 years newly infected with HIV, as shown in graph I.I.

Pregnant women with HIV / AIDS not only have the opportunity to increase maternal mortality but also risk transmitting the disease to their children. This vertical transmission can occur, among other things, during pregnancy, childbirth, or after giving birth through breastfeeding. Transmission of HIV from mother to fetus mainly occurs during the perinatal period, which is when the pregnancy enters the age of 28 weeks to 7 days after giving birth (Ministry of Health, Republic of Indonesia, 20II). Therefore a comprehensive prevention of mother to child HIV transmission (PMTCT) program is implemented or prevention of mother-to-child HIV transmission even from the time the mother plans for her pregnancy to the process of breastfeeding (Setiawan, 2009).

PMTCT is an effort to reduce maternal mortality due to AIDS and give birth to a quality generation (Setiawan, 2009). Providing optimal PMTCT services in developed countries can reduce the risk of HIV transmission from mother to child by up to $2 \%$. However, the lack of HIV / AIDS prevention intervention access in 


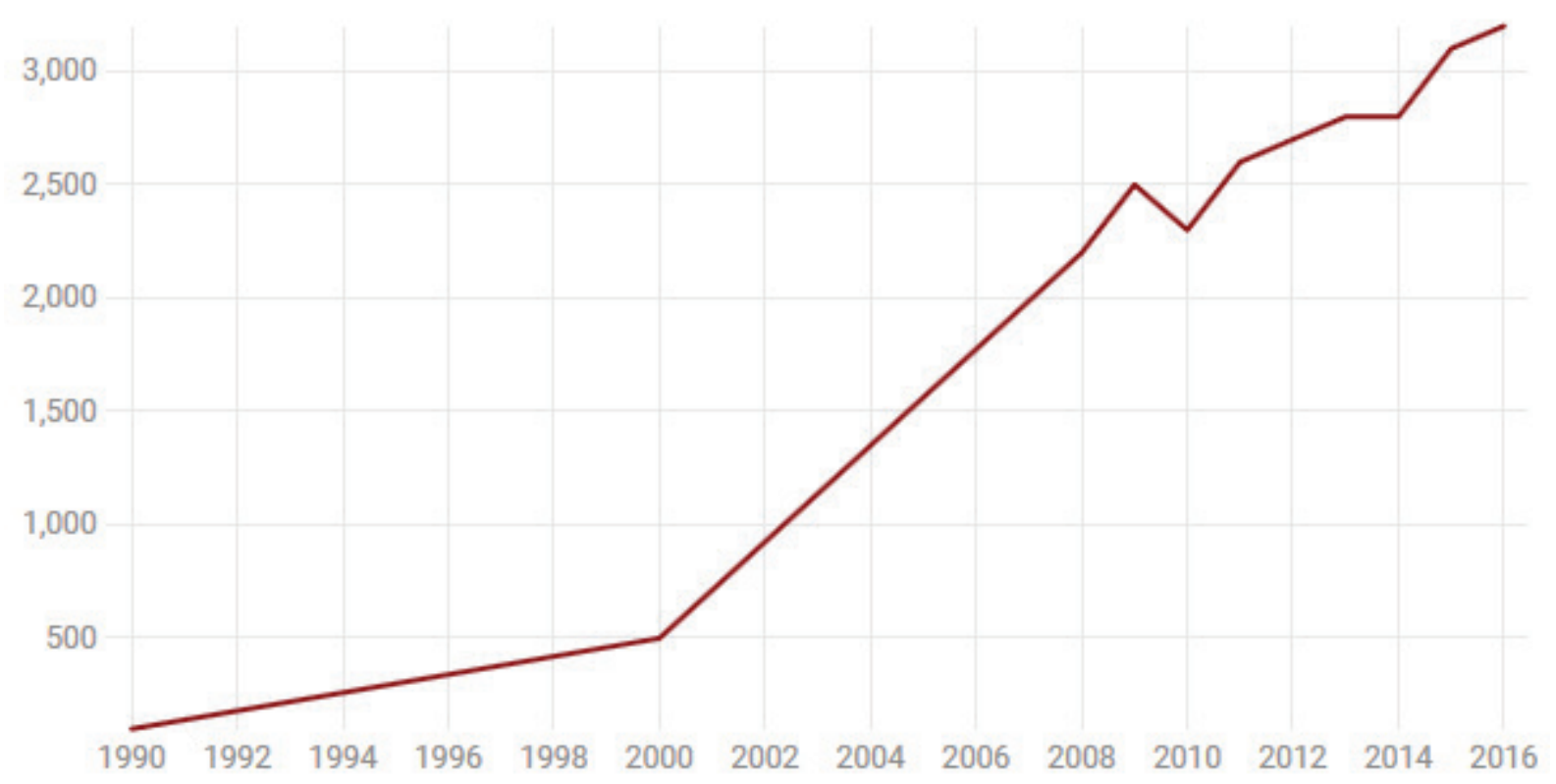

Graph I.I Children (ages o-I4) newly infected with HIV - Indonesia, I990-20I6

Source: World Bank, 2oi7a

developing countries causes the risk of transmission, which is still difficult to suppress, namely $20 \%$ to $50 \%$ (Ministry of Health of the Republic of Indonesia, 20I2). An estimated 8,604 infants with HIV are born each year in Indonesia. The data stated that the implementation of a good PMTCT program is able to prevent $8, \mathrm{II} 2$ babies born with HIV or in other words, can save the cost of caring for babies with HIV by 42 billion rupiahs per year (Muhaimin and Besral, 20II).

PMTCT was carried out by implementing four pillars of strategy or prong following $\mathrm{WHO}$ recommendations (2010). The strategy was further elaborated by the Ministry of Health in some specific activities. Offering HIV testing to all pregnant women, providing antiretroviral treatment (ARV) to pregnant women with HIV/ AIDS, choosing appropriate contraception for women with HIV, choosing safe delivery for pregnant women with HIV/AIDS, and providing food best for babies born to mothers with HIV/ AIDS were the several activities (Ministry of Health, 20I2).

The implementation of PMTCT services is needed to be prioritized. The Ministry of Health projects the number of HIV/AIDS cases in pregnant women who need PMTCT services will increase by $23 \%$, from 13,189 people (2012) to I6,I9I people (2016). Similarly, the number of children under the age of 15 who contracted HIV from their mothers at birth or while breastfeeding increased by $28 \%$, from 4,36 I (20I2) to 5,565 (2016). This condition will increase child mortality due to AIDS (Indonesian Ministry of Health, 20I2). Indonesia, especially in regions with high HIV epidemic rates, has been carrying out PMTCT efforts since 2004. However, unfortunately, until 20II, PMTCT efforts only reached $7 \%$ of the estimated number of mothers who needed these services (Ministry of Health, Republic of Indonesia, 20I2).

Since 2012, PMTCT have been integrated into maternal and child health $(\mathrm{MCH})$ programs, family planning (KB), and adolescent health at every level of health services to increase the range of PMTCT services. The integration of the PMTCT program with the $\mathrm{MCH}$ program is provided through antenatal care checks (Ministry of Health of the Republic of Indonesia, 2012). Research conducted in Bali shows that antenatal testing is essential and needs to be done well because, generally, pregnant women with HIV are at the asymptomatic stage (no visible physical symptoms) (Bagus, 2015). 


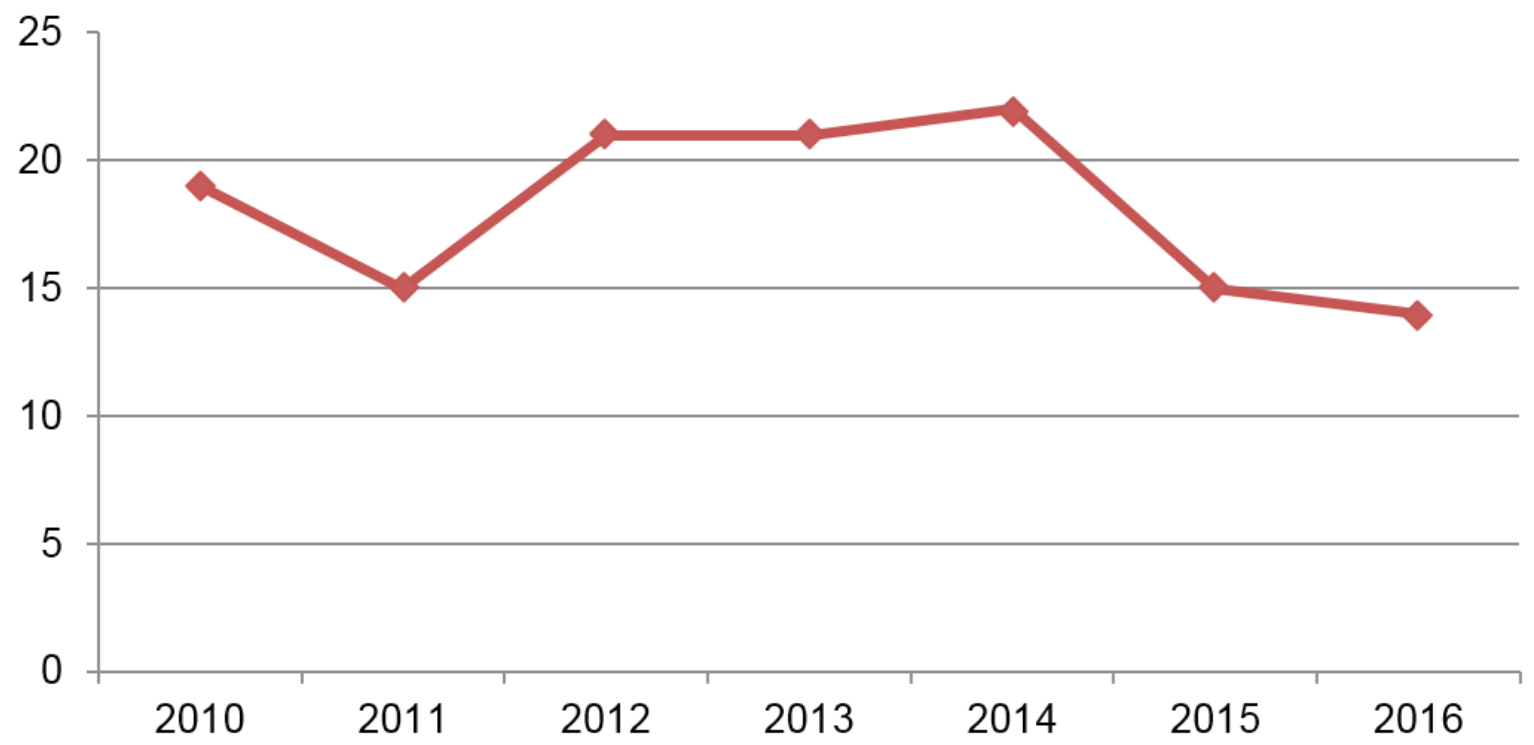

Graph I.2 Antiretroviral therapy coverage for PMTCT (\% of pregnant women living with HIV) in Indonesia, 2010-2016

Source: World Bank, 2oI7b

Increasing the coverage of PMTCT continues to be carried out by health service providers at the primary level (puskesmas) and the referral level (hospital) (Ministry of Health of the Republic of Indonesia, 20II). However, active participation from the target community is needed; in this case, pregnant women to take advantage of PMTCT services. UNAIDS estimation data shows that ARV coverage in pregnant women in Indonesia has decreased since 20I4, as shown in graph I.2. This showed that the utilization of PMTCT services by pregnant women is not yet optimal. As one of the activities in the PMTCT service, ARVs function to suppress the proliferation of viruses in the mother's body. Compliance with antiretroviral treatment by pregnant women is vital in preventing HIV transmission from mother to child.

Research conducted in Semarang showed that pregnant mothers' knowledge about HIV/AIDS and Voluntary Counseling and Testing (VCT) activities were related to the behavior of pregnant women to come and utilize HIV/AIDS counseling and testing services at the puskesmas (Nuraeni et al., 2013). In addition to internal factors within a person, external factors are also proven to influence the health behavior of pregnant women in utilizing PMTCT services. These external factors include the affordability of health services, support, and stigma in the community. Given the information about the users of PMTCT services will increase the PMTCT service program implementation more accurately. Therefore, it is necessary to conduct further research on the utilization factor of PMTCT services by pregnant women.

\section{METHOD}

A method used in this study was a desk review. The critical study was conducted on previous research (articles in journals or case reports). The steps taken in doing desk review were:

I) Searched for the research journals with keywords PMTCT (prevention mother to child HIV transmission), access/ utilization and influencing factors

2) selected the research journal containing the required variables

3) read and abstracted the selected research journals in a table that summarizes the title, author and year of the study, the method, and the results of the study. While the case report used was the result of UNAIDS findings in Indonesia in the form of data and analysis. 


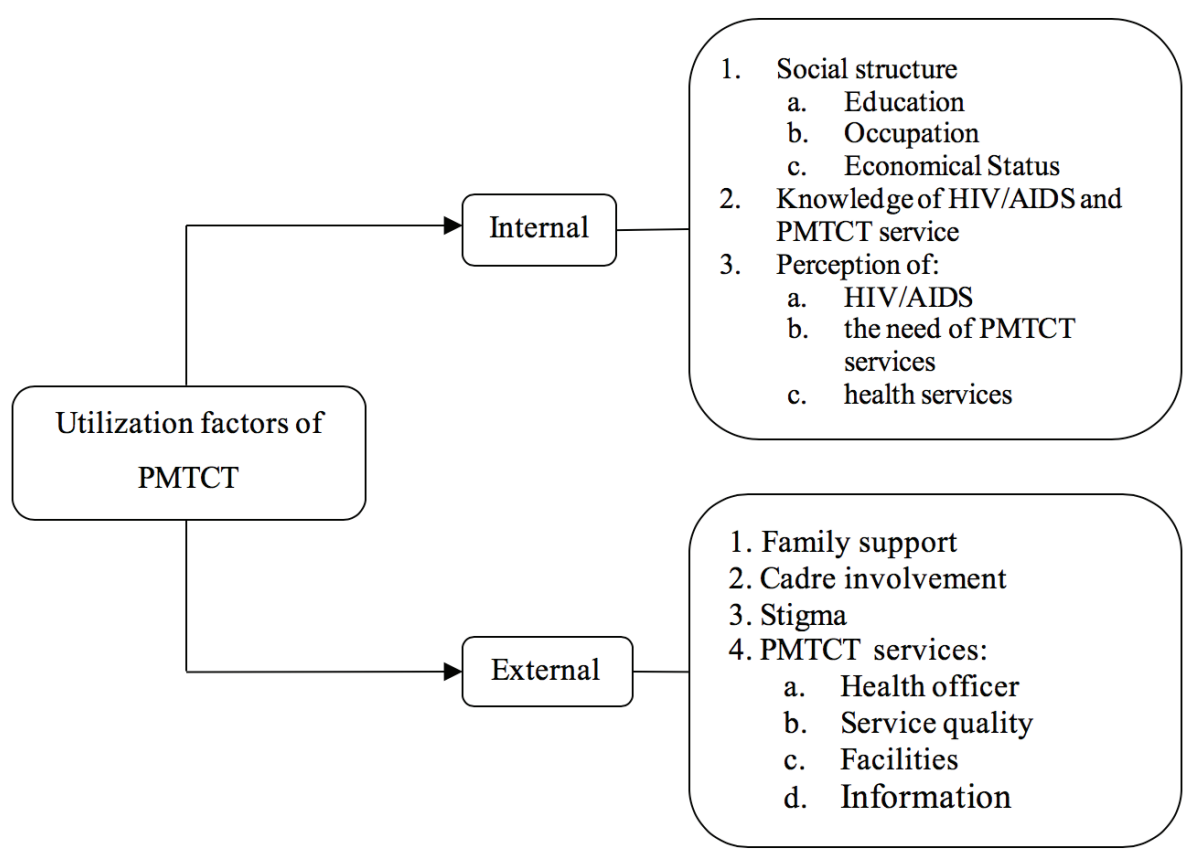

Figure I. Scheme of Research Scope

The analysis in this study was conducted on internal factors and external factors of pregnant women in utilizing PMTCT services. Internal factors consisted of demographic characteristics, knowledge, and perception. Meanwhile, external factors consisted of family support, cadre involvement, community stigma, and PMTCT services themselves. The selection of these variables was based on theories of health service utilization and health behavior theory. These variables were further explained in figure 2.

\section{RESULT}

Utilization of PMTCT services by pregnant women reviewed through I3 works of literature consisted of research articles related to PMTCT services in Indonesia. The literature analyzed in this study provides the results of research conducted in the period 2009-20I7. The utilization of PMTCT services by pregnant women is influenced not only by internal factors within the mother but external factors both from the health service and the community. Therefore, pieces of literature read have provided information from both service providers' and users' viewpoints of PMTCT services.
Research related to PMTCT services that had been reviewed was $29 \%$ used quantitative methods, 57\% used qualitative methods, and I $4 \%$ used quantitative and qualitative methods simultaneously. Data and information from quantitative studies were used to get ideas or answers related to factors behind the use of PMTCT services by pregnant women, while information from qualitative studies provides a better understanding of these factors. In addition, $29 \%$ of the literature reviewed took the perspective of PMTCT service providers, $43 \%$ used the viewpoints of users of services, both pregnant women, couples, and their families, and $28 \%$ of literature used the viewpoints of both users and providers of PMTCT services.

Several studies had the rates of utilization of PMTCT services by pregnant women. The utilization rates for PMTCT services were diverse. Based on several studies conducted in 2015, the proportion of pregnant women who used PMTCT services varied with the lowest value of $24 \%$ and the highest of $59 \%$ (Bangli, 2015, Romdiyah, 2017). The considerable variation in the number of PMTCT service utilization could occur in one city or district area even though it has similar community and policy characteristics. 
Furthermore, the identification of internal and external factors relating to the utilization of PMTCT services by pregnant women was described below.

\section{Internal factors}

In general, the results of the literature review showed that internal factors such as social structure (education, employment, and economic status) are not significantly related to the utilization of PMTCT services. It was known through three studies using PMTCT that had educational variables and one study that discussed work variables. While economic status variables were indirectly discussed in one study. Internal factors that influenced each other and significantly contributed to the behavior of PMTCT service utilization were knowledge about HIV/AIDS, knowledge about PMTCT, perceptions of HIV / AIDS, perceptions of the need for PMTCT services, and perceptions of health services. It was known through three studies discussed knowledge variables about HIV/AIDS; four studies discussed knowledge variables about PMTCT, two studies discussed perceptions of HIV/ AIDS, two studies discussed perceptions of demand for PMTCT services, and three studies discussed perceptions of services health.

\section{External factors}

This factor originated from outside pregnant women both in the social environment and the provision of PMTCT services themselves. The social environment of the mother consisted of the family, community, and the place where the mother receives PMTCT services. In addition, there was a complicated relationship between health workers, cadres, and the community that results in increased utilization of health services to pregnant women (Giri et al., 20I7). Compared with internal factors, more studies discussed the external factors related to the utilization of PMTCT services. This was indicated by three studies that discussed family support variables, two studies that discussed cadre involvement variables, eight studies that discussed negative stigma, six studies that discussed health worker variables in PMTCT services, six studies that discussed PMTCT service quality variables, three studies discussed facility variables and PMTCT service infrastructure, as well as five studies discussed about information affordability variables related to PMTCT services.

\section{DISCUSSION}

\section{Internal factors}

These factors originated within pregnant women, which included characteristics, knowledge, and attitudes to encourage or hinder the utilization of PMTCT services.

\section{a. Social structure}

\section{- Education}

Education is one of the demographic characteristics that usually associated with a person's ability to receive or find information. Therefore, this variable was also related to knowledge, where higher education is, the better the knowledge will be (Meilani, 2015). After that, pregnant women would make good use of PMTCT services.

However, three studies involving education proved that education was not significantly related to the behavior of PMTCT service utilization. The proportion of pregnant women with both high and low education who used and who did not use PMTCT services was almost the same. One of the utilization of PMTCT services seen was HIV testing behavior. This because there was inaccurate information that believed by most mothers; for example, HIV status could be known from antenatal care and maternal ignorance of HIV transmission through childbirth (Meilani, 2015r, Romdiyah, 2017). 


\section{- Occupation}

This variable was related to the time available for mothers to use PMTCT services because it caused by other activities such as work. The research examined mothers' work shows that the majority of mothers who make good use of PMTCT services were mothers who do not work. But among working mothers, the proportion of mothers who used PMTCT services was more significant than those who did not. Therefore, there was no significant relationship between mother's work and PMTCT service utilization behavior (Romdiyah, 20I7).

\section{- Economical status}

This variable referred to income from mothers and their partners, so they have the financial ability to access PMTCT services. The cost of PMTCT services would differ between puskesmas, clinics, and hospitals. Generally, PMTCT service costs at puskesmas were free. However, some services cannot be fulfilled at the puskesmas, such as cesarean section during childbirth. Besides, the hospital also provided better privacy. Therefore, economic status influenced pregnant women in choosing where PMTCT services are provided, whether in the puskesmas or the hospital (Hardon et al., 2009).

\section{b. Knowledge}

\section{- HIV/AIDS}

Knowledge about HIV / AIDS was intended, among others, on the mode of transmission, the incubation period of the virus, symptoms, and its effects. Lack of knowledge made pregnant women tend to be late in knowing their HIV status so that HIV testing of pregnant women was done after their husband or child experiences symptoms and is diagnosed with HIV. Conversely, if mothers had good knowledge about HIV, then the likelihood of mothers to utilize PMTCT services would be even higher (Nuraeni et al., 2013, Mujiati, 2015, Romdiyah, 20I7).

\section{- PMTCT services}

In addition to knowledge about HIV / AIDS, pregnant women also need to know about PMTCT services before utilizing it. Research that had been done shows that sufficient knowledge about PMTCT services will increase the motivation of mothers to utilize these services. Knowledge obtained by mothers about PMTCT services is that PMTCT is part of antenatal care (ANC), which is usually accessed by pregnant women. In addition, according to the knowledge of pregnant women, PMTCT services were free of charge and provided additional food for infants (Hardon et al., 2009, Nasution et al., 2012, Giri et al., 2017). However, some women still had lack knowledge about the goals of ARV treatment. Some mothers still did not give ARVs to their babies correctly and adequately because they felt sorry for their babies (Demartoto et al., 2017).

\section{c. Perception}

\section{- HIV/AIDS}

Most pregnant women agreed that HIV/AIDS was a dangerous disease for themselves and their children. However, the majority of pregnant women had a perception that there was no risk of contracting HIV/AIDS. It was the reason why some pregnant women refuse to do HIV testing. This risk-free perception could occur because most respondents were housewives, so they assumed that their behavior was far from risky behaviors of contracting HIV and AIDS (Meilani, 20I5). 


\section{- $\quad$ PMTCT services needed}

PMTCT services were one of the facilities provided to prevent HIV transmission from mothers to their children. The results of previous studies indicated that pregnant women tend to be positive towards PMTCT services. The proportion of pregnant women who did not make good use of PMTCT services was more found in mothers who had attitudes about preventing HIV transmission that were less supportive than those who had attitudes about preventing HIV transmission that was supportive (Romdiyah, 20I7).

\section{- Health service}

Health services were considered to be less than optimal in providing information on the prevention of HIV transmission from mother to baby so that pregnant women have less knowledge about PMTCT services. In addition, the speed and confidentiality of HIV testing were factors that influence the willingness of mothers to carry out HIV testing during pregnancy (Hardon et al., 2009). Some pregnant women also had a perception that the private sector provides better health services than puskesmas, so they have more access to clinics or private hospitals. It was consistent with the theory of health service utilization, which reveals that the behavior of health service search was influenced by the desire to get better services (Giri et al., 20I7).

\section{External factors}

\section{a. Family support}

The significant figure for pregnant women who could provide support was her partner, child, brother, or mother in law. Support provided in the form of emotional support, instruments, and awards. The emotional support that is listening to complaints, encouraging, and reminding mothers to take ARV drugs because forgetting is the main reason for non-compliance with this ARV therapy. Instrument support was in the form of money, place of residence, energy, and time (Larasaty, 2015). The involvement of couples with every pregnant woman utilizing PMTCT services was a form of husband support. Most pregnant women who used PMTCT services were always accompanied by their husbands, even when the visit was adjusted to the husband's free time (Giri et al., 20I7).

\section{b. Cadre involvement}

PMTCT services were initially carried out in the form of VCT. It was expected to be accepted by productive reproductive mothers or women voluntarily. The active role of health cadres in the community was needed. One of them was participating cadres in providing information about PMTCT services. Providing information by cadres to pregnant women could increase the motivation of mothers to get services (Hardon et al., 2009). Also, the cadre was also discussed with the activist in asking the mother to access PMTCT services (Giri et al., 20I7).

\section{c. Stigma}

Pregnant women obtained negative stigma both from the family, community, and even from health workers. The stigma found became heavier not only because of HIV but also because the person with HIV was a woman. The stigma against HIV that was still very thick in the community makes pregnant women afraid to know their HIV status (Meilani, 20I5). Besides, this stigma caused the mother not to follow the procedure as recommended in the PMTCT (Hardon et al., 2009). Mothers who knew their HIV status through community health centers or VCT activities in the community tend to fear that other mothers will know their status. Pregnant women with HIV chose not to join communities 
such as PKK for fear of being disseminated in the community (Hardon et al., 2009).

Some health workers had a negative stigma against people with HIV / AIDS, including pregnant women. This stigma from health workers encouraged discriminatory treatment (Nasution et al., 2012, Demartoto et al., 20I7). Efforts were made to overcome the stigma in health workers is the holding of training. However, training tried to carry out only to increase knowledge but do not improve negative attitudes in pregnant women for fear of contracting (Liem and Adiyanti, 2013, Susilowati, 2014). For some health workers, the training conducted should be able to reduce anxiety because transmission could be prevented by the use of personal protective equipment and actions according to procedures (Angkasawati et al., 2009).

\section{d. PMTCT services}

\section{- Health officers}

Health workers still lack both in quantity and quality in implementing PMTCT services. These limitations on numbers made a health worker must be responsible for several things at once. In addition, in terms of quality, the role of health workers in informing and reminding mothers to access PMTCT services, complying with ARV treatment, or directing mothers to carry out HIV testing was still lacking (Ministry of Health of the Republic of Indonesia, 20II, Larasaty, 2015). In fact, the initiation of health service providers or PITC (provider-initiated testing and counseling) at puskesmas statistically showed a relationship with the behavior of pregnant women on HIV testing, which was one of the activities in PMTCT services (Meilani, 20I5).

This lack of a role for health workers could also be caused by the fact that most health workers did not understand the procedures for implementing PMTCT services (Susilowati, 20I4). Lack of information and counseling provided by health workers often created unequal relations between pregnant women and health workers. One of them was shown by the sterilization action after the mother gives birth. This action was communicated to the husband or mother shortly after giving birth so that the information provided was less comprehensive but still agreed by the mother and her partner (Nasution et al., 2012, Demartoto et al., 20I7).

\section{- Service quality}

PMTCT services were an amalgamation of infectious disease prevention programs and maternal and child health $(\mathrm{MCH})$. Generally, PMTCT services were not a priority compared to other activities such as immunization, improvement of nutrition for mothers and toddlers, and family planning. Therefore, the implementation of PMTCT services was still not optimal due to weak coordination, supervision, monitoring, and evaluation (Nasution et al., 20I2, Ministry of Health, Republic of Indonesia, 20II, Susilowati, 20I4, Angkasawati et al., 2009). Besides, the availability of resources and affordability of health facilities made the quality of PMTCT services different in each city (Nasution et al., 2012).

Quality or quality was a dynamic situation relating to resources, processes, products, and services that meet or exceed the expectations of service users. Quality assessment was usually in the form of perception or interpretation of several indicators (Al-Assaf, 2009). These indicators included empathy, accuracy, responsiveness, communicative, and caring. In general, PMTCT services performed 
were still focused on the curative or treatment stage, not yet oriented towards users of PMTCT (clientoriented system) services (Badriah et al., 20I7). Most of the mothers who used PMTCT services had not received counseling services related to contraception, delivery, and supplementary feeding to infants (Nasution et al., 20I2).

\section{- Facilities}

The implementation of PMTCT services that were integrated with ANC had a lack of facilities in the form of counseling rooms, brochures and leaflets as a medium of socialization (Badriah et al., 20I7, Giri et al., 20I7). This lack of facilities and infrastructure has affected the implementation of counseling activities and providing information from health workers to pregnant women less than optimal. In addition, additional puskesmas with VCT services in areas with a high risk of HIV were needed to conduct PMTCT services in the area (Ministry of Health, Republic of Indonesia, 2OII).

\section{- Information affordability}

Necessary information regarding HIV and PMTCT services obtained by pregnant women was classified as low even though exposure to information about HIV can make mothers access PMTCT services. One way was to come and want to do an HIV check (Nasution et al., 20I2, Muhaimin and Besral, 20II, Badriah et al., 20I7). Information regarding PMTCT services was usually obtained from NGOs conducting socialization or from peer support groups in specific communities. Besides, if the mother had been proven to have a positive HIV status, the mother or her partner will find their information through the mass media or the internet (Demartoto et al., 20I7). Comprehensive information that should have been obtained from health workers, for example, related to sterilization measures, breastfeeding formula replacement, or counseling related to family planning, was still not given optimally (Nasution et al., 20I2, Demartoto et al., 2017). The availability of information both from families and health workers needed to be improved because it was related to the behavior of mothers in utilizing PMTCT services (Meilani, 20I5, Demartoto et al., 20I7).

\section{CONCLUSION}

Demographic characteristics such as education, employment, and economic status were internal factors that do not directly influence the behavior of PMTCT service utilization by pregnant women. Education was related to the ability of pregnant women to absorb information. Work is related to the time available for pregnant women. Economic status was related to the financial ability of pregnant women to access PMTCT services from better health facilities. Also, proper knowledge about HIV/AIDS and PMTCT services would increase the chances of pregnant women to make optimum use of PMTCT services. Furthermore, the perception was related to the behavior of PMTCT service utilization so that when a pregnant woman had a perception that she is not at risk of contracting HIV, pregnant women tend to refuse to utilize PMTCT services. However, pregnant women tend to have a positive perception of PMTCT services and health services.

External factors such as family support and cadre involvement encouraged behavior in the utilization of PMTCT services by pregnant women. Negative stigma from health workers and the community tends to prevent pregnant women from utilizing PMTCT services optimally. Besides, in terms of PMTCT service providers, both health workers, service quality, facilities, and infrastructure, as well as affordability of information, were still 
not optimal could increase the utilization of PMTCT services by pregnant women.

Internal and external factors related to the use of PMTCT services interacted with each other to shape maternal behavior. Availability of information and consultation from health workers (external factors) related to the knowledge and perceptions of mothers (internal factors) regarding HIV and activities in PMTCT services. Good knowledge and perception from mothers would be directly related to the maximum utilization of PMTCT services. However, external factors in the form of negative stigma from both family and community made pregnant women reluctant to utilize PMTCT services both to check their HIV status and chose to carry out proper childbirth procedures for pregnant women with HIV/AIDS.

\section{RECOMMENDATION}

PMTCT service providers needed to improve the quality of client-oriented services, including through the friendliness and neutrality of health workers in serving pregnant women with HIV and expanding the reach of information for the general public regarding HIV and PMTCT services. Information obtained by the public would affect the increase in knowledge, perceptions, and reduced the negative stigma among the community towards pregnant women with HIV. It will lead to optimizing the utilization of PMTCT services.

\section{REFFERENCES}

Al-Assaf, A. F. (2009). Mutu Pelayanan Kesehatan: Perspektif Internasional, Jakarta, Penerbit Buku Kedokteran EGC.

Demartoto, A. Zunariyah, S., \& Soemanto, RB. (2017). The Representation of Prevention of Mother-to-Child Transmission Service System in Surakarta Indonesia. Jurnal Kesehatan Masyarakat I3, I9I-200.

Nasution, B.R., Mukuan, O.S., Sebayang, P.M., Aznur, S.D., \& Sunarsih, S. (20I2). Kualitas dan rekomendasi perbaikan layanan PMTCT bagi perempuan terinfeksi HIV di 4 Kota di Indonesia. Jakarta: Ikatan Perempuan Positif Indonesia.
Dinas Kesehatan Kabupaten Bangli. (20I5). Laporan Kesehatan Ibu dan Anak. Bangli: Dinas Kesehatan Kabupaten Bangli.

Cassels, S., Jenness, S. M., Biney, A. A. E. \& Dodoo, F. N.-A. (20I7). Geographic mobility and potential bridging for sexually transmitted infections in Agbogbloshie, Ghana. Social Science \& Medicine, I84, 27-39.

Dever, G.E.A. (I984). Epidemiology in Health Services Management, United States of America, Aspen Publishers, Inc.

Dirjen Pencegahan Penyakit dan Pengendalian Lingkungan Kemenkes RI. (20I7). Laporan Situasi Perkembangan HIV/AIDS di Indonesia Januari-Maret 20I7. Jakarta: Kementerian Kesehatan RI.

Dwi Aryana, M. B. (2015). Karakteristik Ibu Hamil Dengan HIV di RSUP Sanglah Denpasar Tahun 2005-2010. E-Journal Obstetric \& Gynecology Udayana 3(4).

Badriah, M.T.F., Tahangnacca, M., Alkaff, R., Abe, T., \& Hanifah, L. (20I7). Implementation of Program for the Prevention of Mother-toChild Transmission of HIV in South Jakarta. Kesmas: National Public Health Journal, I2(4), I59-I64.

Hardon, A. P., Oosterhoff, P., Imelda, J. D., Anh, N. T. \& Hidayana, I. (2009). Preventing motherto-child transmission of HIV in Vietnam and Indonesia: Diverging care dynamics. Social Science \& Medicine, 69, 838-845.

Ilyas, Y. (2006). Mengenal Asuransi Kesehatan. Review Utilisasi, Manajemen Klaim, dan Fraud (Kecurangan Asuransi Kesehatan), Depok, Fakultas Kesehatan Masyarakat, Universitas Indonesia.

Perkumpulan Keluarga Berencana Indonesia. (20I6). Pendekatan HIV Harus Lebih Inovatif dan Inklusif - Refleksi PKBI pada Hari AIDS Sedunia 2016 [Online]. Available: https://pkbi. or.id/pendekatan-hiv-harus-lebih-inovatifdan-inklusif-refleksi-pkbi-pada-hari-aidssedunia-20i6/ [Accessed May i8th 20I7].

Giri, K.E., Nopiyani N.M.S., \& Merati, T.P. (20I7). Barriers and opportunities for implementing prevention of mother to child transmission (PMTCT) in Bangli District. Public Health and Preventive Medicine Archive, 5.

Larasaty, N. D. (20I5). Bentuk-Bentuk Dukungan Keluarga Kepada Ibu Dengan Hiv Positif Dalam Menjalani Terapi ARV (Studi Kasus pada Kelompok Dukungan Sebaya/KDS Ar- 
juna Plus Kota Semarang). The 2nd University Research Coloquium.

Liem, A. \& Adiyanti, M. G. (2013). "Bidan cantik": Psychoeducation on HIV and AIDS to improve the service quality of midwives at Yogyakarta public health center. HIV \& AIDS Review, 12, I4-22.

Madunde, K. J., Pelealu, F. J. \& Kawatu, P. (20I4). Faktor-Faktor yang Berhubungan dengan Pemanfaatan Pelayanan Kesehatan di Puskesmas Kema Kecamatan Kema Kabupaten Minahasa Utara. Fakultas Kesehatan Masyarakat Universitas Sam Ratulangi Manado.

Maro, E. W., Mosha, N. R., Mahande, M. J., Obure, J. \& Masenga, G. (20I6). Ten years trend in maternal mortality at Kilimanjaro Christian Medical Center Tanzania, 2003-2012: A descriptive retrospective tertiary hospital based study. Asian Pacific Journal of Reproduction, 5, 214-220.

Mujiati, H. L. (2015). Pengguna Layanan Pencegahan Penularan HIV dari lbu ke Anak (PMTCT di Rumah Sakit Rujukan HIV-AIDS di Provinsi Jawa Barat. Jurnal Kesehatan Reproduksi, 6.

Setiyawati, N.M.N. (20I5). Determinan Perilaku Tes HIV pada Ibu Hamil. Kesmas: Jurnal Kesehatan Masyarakat Nasional, 9.

Notoatmodjo, S. (2012). Promosi Kesehatan dan Perilaku Kesehatan, Jakarta, PT Rineka Cipta.

Nuraeni, T., Indrawati, N. D. \& Rahmawati, A. (2013). Hubungan Pengetahuan Ibu Hamil tentang HIV/AIDS dan VCT dengan Sikap terhadap Konseling dan Tes HIV/AIDS Secara Sukarela di Puskesmas Karangdoro Semarang. Jurnal Kebidanan.

Kementerian Kesehatan RI. (20II). Kajian Implementasi Program Pencegahan Penularan HIV/ AIDS dari Ibu ke Anak. Jakarta: Kementerian Kesehatan.

Kementerian Kesehatan RI. (20I2). Pedoman Pencegahan Penularan HIV dari lbu ke Anak. In: Dirjen Pencegahan Penyakit dan Pengendalian Lingkungan. Jakarta: Dirjen P2PL Kementerian Kesehatan RI.

Kementerian Kesehatan RI. (20I3). Peraturan Menteri Kesehatan Republik Indonesia Nomor $5 \mathrm{I}$ Tahun 2013 tentang Pedoman Pencegahan
Penularan HIV dari Ibu ke Anak. Jakarta: Kementerian Kesehatan.

Kementerian Kesehatan RI. (2016a). Estimasi dan Proyeksi HIV/AIDS di Tahun 20I2-20I6. Jakarta: Kementerian Kesehatan.

Kementerian Kesehatan RI. (20I6b). Petunjuk Teknis Program Pengendalian HIV AIDS dan PIMS Fasilitas Kesehatan Tingkat Pertama. Jakarta: Dirjen P2PL.

Pusdatin Kemenkes RI. (20I6c). Situasi Penyakit HIV/ AIDS di Indonesia. Jakarta.

Romdiyah, N. N. (20I7). Analisis Perilaku Pencegahan Penularan HIV/AIDS pada Ibu Hamil di Puskesmas Kalikajar I Wonosobo. Bidan Prada: Jurnal Ilmiah Kebidanan,, 8, 67-79.

Setiawan, S. (2009). Management of HIV/AIDSInfection in Infants and Children. Journal of the Indonesian Medical Association, 59.

Susilowati, Y. A. (20I4). Kajian Situasi Pelaksanaan Prevention Of Mother-To Child Transmission (PMTCT) di RSUD Kota C Jawa Barat. Jurnal Kesehatan STIKES Santo Borromeus.

Muhaimin, B.T. (20II). Prevalensi HIV pada Ibu Hamil di Delapan Ibu Kota Provinsi di Indonesia tahun 2003-20I0. Makara Kesehatan, I5, 93-100.

Angkasawati, T.J., \& Arifin, A. (2009). Kesiapan Petugas Puskesmas dalam Penanggulangan Infeksi Menular Seksual dan HIV/AIDS Pada Pelayanan Antenatal. Buletin Penelitian Sistem Kesehatan, I2, 403-408.

Wiley, J. \& Sons. (2005). Models of Health Care Utilization and Behavior. Encyclopedia of Biostatistics.

World Bank. (20I7a). Children (ages O-I4) newly infected with HIV. Available: https://data.worldbank. org/indicator/SH.HIV.INCD.I4?locations=ID (Accessed June 23 20I7).

World Bank. (20I7b). Antiretroviral therapy coverage for PMTCT (\% of pregnant women living with HIV). Available: https://data.worldbank.org/ indicator/SH.HIV.PMTC.ZS?locations=ID (Accessed June 23 20I7). 